\title{
Runx3 inhibits endothelial progenitor cell differentiation and function via suppression of HIF-1 $\alpha$ activity
}

\author{
SO-YUN CHOO ${ }^{1-3}$, SOO-HYUN YOON ${ }^{1-3}$, DONG-JIN LEE ${ }^{1-3}$, SUN HEE LEE $^{1,2}$, KANG LI $^{1-3}$, \\ IN HYE KOO ${ }^{3}$, WOOIN LEE ${ }^{3}$, SUK-CHUL BAE $^{4}$ and YOU MIE LEE ${ }^{1-3}$ \\ ${ }^{1}$ BK21 Plus KNU Multi-Omics Creative Drug Research Team and ${ }^{2}$ Research Institute of Pharmaceutical Sciences, \\ Kyungpook National University; ${ }^{3}$ National Basic Research Laboratory of Vascular Homeostasis Regulation, \\ College of Pharmacy, Kyungpook National University, Daegu 41566; ${ }^{4}$ Department of Biochemistry, \\ School of Medicine, Institute of Tumor Research, Chungbuk National University, Chungju 28644, Republic of Korea
}

Received July 9, 2018; Accepted November 30, 2018

DOI: $10.3892 /$ ijo.2019.4713

\begin{abstract}
Endothelial progenitor cells (EPCs) are bone marrow (BM)-derived progenitor cells that can differentiate into mature endothelial cells, contributing to vasculogenesis in the blood vessel formation process. Runt-related transcription factor 3 (RUNX3) belongs to the Runt domain family and is required for the differentiation of specific immune cells and neurons. The tumor suppressive role of RUNX3, via the induction of apoptosis and cell cycle arrest in a variety of cancers, and its deletion or frequent silencing by epigenetic mechanisms have been studied extensively; however, its role in the differentiation of EPCs is yet to be investigated. Therefore, in the present study, adult BM-derived hematopoietic stem cells (HSCs) were isolated from Runx3 heterozygous $\left(\mathrm{Rx}^{+/-}\right)$ or wild-type (WT) mice. The differentiation of EPCs from the BM-derived HSCs of $\mathrm{R} \times 3^{+/-}$mice was found to be significantly increased compared with those of the WT mice, as determined by the number of small or large colony-forming units. The migration and tube formation abilities of $\mathrm{R} \times 3^{+-} \mathrm{EPCs}$ were also observed to be significantly increased compared with those of WT EPCs. Furthermore, the number of circulating EPCs, defined as CD34 ${ }^{+}$vascular endothelial growth factor receptor 2 (VEGFR2) ${ }^{+}$cells, was also significantly increased in $\mathrm{Rx}^{+/-}$mice. Hypoxia-inducible factor (HIF)-1 $\alpha$ was upregulated in $\mathrm{R} \times 3^{+/-}$EPCs compared with WT EPCs, even under normoxic conditions. Furthermore, in a hindlimb ischemic mouse models, the recovery of blood flow was observed to be highly stimulated in $\mathrm{R} \times 3^{+/-}$mice compared with WT mice. Also, in a Lewis lung carcinoma cell allograft model,
\end{abstract}

Correspondence to: Dr You Mie Lee, National Basic Research Laboratory of Vascular Homeostasis Regulation, College of Pharmacy, Kyungpook National University, 80 Daehakro, Bukgu, Daegu 41566, Republic of Korea

E-mail: lym@knu.ac.kr

Key words: Runx3, vasculogenesis, endothelial progenitor cell, vascular endothelial growth factor receptor 2 signaling, ischemia, hypoxia-inducible factor the tumor size in $\mathrm{Rx}^{+/-}$mice was significantly larger than that in WT mice, and the EPC cell population (CD34+/VEGFR2 ${ }^{+}$ cells) recruited to the tumor was greater in the $\mathrm{R} \times 3^{+/-}$mice compared with the WT mice. In conclusion, the present study revealed that Runx3 inhibits vasculogenesis via the inhibition of EPC differentiation and functions via the suppression of HIF-1 $\alpha$ activity.

\section{Introduction}

The Runt-related transcription factor (RUNX) family comprises context-dependent transcriptional regulators including RUNX1, RUNX2 and RUNX3 in humans. The RUNX family has a highly conserved Runt-homology domain that mediates site-specific DNA binding and interactions with various proteins $(1,2)$. RUNX1 is essential for hematopoiesis; RUNX2 is involved in osteogenesis during bone formation, and RUNX3 is expressed in epithelial, neuronal and hematopoietic stem cells, and is involved in the transforming growth factor (TGF)- $\beta$ signaling pathway (3), in which it functions to control the lineage differentiation of hematopoietic and neuronal progenitor cells (4). RUNX3 has been documented to function as a tumor suppressor in numerous types of tumors (5). Under hypoxic conditions, RUNX3 is silenced by histone deacetylation and methylation via histone deacetylase 1 and G9a histone methyltransferase, respectively (6).

Blood vessel formation occurs via two distinct mechanisms, namely vasculogenesis and angiogenesis; angiogenesis comprises endothelial sprouting and intussusception from pre-existing vessels, while vasculogenesis initiates from vascular stem cells or hemangioblasts in the developing embryo or adult bone marrow (BM) (7). Endothelial progenitor cells (EPCs), mainly derived from BM hemangioblasts and hematopoietic stem cells (HSCs), possess an ability to self-renew, mobilize into the circulatory system, migrate to sites of neovascularization and differentiate into mature endothelial cells contributing to neonatal vasculogenesis as well as tumor vasculature (8-10). Generally, EPCs can be obtained by isolating a heterogeneous subpopulation of BM-derived mononuclear cells (MNCs) that respond to stresses, such as tissue ischemia and vascular-damaging signals $(11,12)$. In a previous study, 
an EPC colony-forming unit (CFU) assay was used to discriminate the hierarchical lineage between primitive (small colony) and definitive (large colony) CFUs in vitro (13). These EPC CFUs take up 3,3'-dioctadecylindocarbocyanin-labeled acetylated low-density lipoprotein (Dil-Ac-LDL), bind with isolectin B4, and express vascular endothelial growth factor (VEGF) receptor 2 (VEGFR2) and endothelial nitric oxide synthase (eNOS) independent of BM-MNC isolation markers $(13,14)$. Using a short-term protocol (4-7 days culture), it is possible to obtain cells with myeloid/hematopoietic and typical endothelial cell markers that function as therapeutics in ischemic diseases $(15,16)$.

Cord blood-derived EPCs enhance tissue neovascularization via physical incorporation into the ischemic area and the perivascular paracrine effect (17). Hypoxia or ischemic stress is a stimulator of EPC function through the activation of hypoxia-induced signaling molecules, such as signal transducer and activator of transcription 3 in the preconditioning to hypoxia (18). A number of studies have demonstrated that EPCs promote the angiogenic switch in solid tumors, thereby increasing tumor growth and metastasis (10). Likewise, the genetic suppression of EPC mobilization from BM inhibits tumor development and colonization to remote organs (19). These findings indicate that EPCs may be used as cell therapeutics in injured or regenerative tissues, and also as therapeutic targets for the inhibition of tumor growth or metastasis.

In a previous study, the present research team identified a new function of RUNX3 that facilitates the degradation of hypoxia-inducible factor (HIF)- $1 \alpha$ by promoting the interaction of proline hydroxylases (PHDs) with HIF-1 $\alpha$, thus inhibiting hypoxia-induced VEGF secretion and angiogenesis in vitro and in vivo (20). Hypoxia is a critical microenvironment for the differentiation and maintenance of hematopoietic stem cells $(18,21)$ and leukemia development $(22)$. However, the role of Runx3 in the differentiation and function in EPCs has not yet been investigated.

In the present study, using a Runx3 heterozygous deletion mutant mouse model, it was demonstrated that the mouse homolog Runx3 inhibits vasculogenesis via the suppression of EPC differentiation and function. The mobilization of EPCs into peripheral blood (23), their differentiation into neovessels and homing to an ischemic limb region was significantly increased in Runx3 heterozygous mice. Signaling pathways involved in the maintenance or function of EPCs, as well as HIF-1 $\alpha$ were also significantly upregulated by Runx3 heterozygous deletion. These results suggest that Runx3 suppresses EPC function and differentiation from BM-derived MNCs by the suppression of HIF-1 $\alpha$.

\section{Materials and methods}

Mice. The animal experiments were approved according to the guidelines for care and use of laboratory animals by the Kyungpook National University Institutional Animal Care and Use Committee (Daegu, Korea). FVB/N male mice ( $\mathrm{n}=10$, 4-6 weeks old, 10-12 g; Japan SLC, Inc., Hamamatsu, Japan) were maintained under specific pathogen-free conditions with a constant humidity and temperature at $26^{\circ} \mathrm{C}$, filtered air and a 12/12-h light/dark cycle. Mice were treated with $\mathrm{CO}_{2}$ by inhalation in a chamber for anesthesia, immediately prior to sacrifice. Runx3 heterozygous mice $\left(\mathrm{Rx}^{+/-}\right)$were generated as previously reported (24).

Isolation of mouse MNCs from BM and PB, and hypoxic conditions. MNCs were isolated from the $\mathrm{BM}$ or $\mathrm{PB}$ of wild-type (WT) and $\mathrm{Rx} 3^{+/-}$mice using a Histopaque ${ }^{\circledR}-1083$ density gradient centrifugation method (Sigma-Aldrich; Merck KGaA, Darmstadt, Germany) according to the manufacturer's instructions. Briefly, BM or PB cells were centrifuged at $400 \mathrm{x}$ g for $30 \mathrm{~min}$ at room temperature following the addition of Histopaque-1083 and MNC-containing layers were isolated. The freshly isolated MNCs were washed with $5 \mathrm{mM}$ EDTA in PBS and suspended in $4 \mathrm{ml}$ of $0.8 \%$ ammonium chloride (StemCell Technologies, Inc., Vancouver, BC, Canada) for $5 \mathrm{~min}$ at $4^{\circ} \mathrm{C}$. The MNCs were then resuspended in Endothelial Cell Growth Medium (EGM)-2 (Lonza Group, Ltd., Basel, Switzerland) supplemented with 5\% fetal bovine serum (FBS; Hyclone; GE Healthcare Life Sciences, Logan, UT, USA), basic fibroblast growth factor (bFGF; R\&D Systems, Wiesbaden, Germany), VEGF (PeproTech, Inc., Rocky Hill, CT, USA), insulin-like growth factor-1 (R\&D Systems), epidermal growth factor (EGF; PeproTech, Inc.), ascorbic acid and heparin (Sigma-Aldrich; Merck KGaA), and then seeded onto $60-\mathrm{mm}$ dishes coated with $2 \%$ gelatin $\left(2 \times 10^{7}\right.$ cells/dish). After culture for 3 days at $37^{\circ} \mathrm{C}$, the non-adherent cells were removed by washing with $\mathrm{PBS}$, and the attached cells were cultured for a further 4 days. These cells are designated 'early EPCs' $(15,16)$. For exposure of the early EPCs to hypoxic conditions, hypoxic chambers (Thermo Fisher Scientific, Inc., Waltham, MA, USA and Astec Co., Ltd., Kasuya, Japan) were used for maintaining low oxygen tension $\left(1 \% \mathrm{O}_{2}\right.$ and $5 \% \mathrm{CO}_{2}$, balanced with $\mathrm{N}_{2}$ ).

EPC colony-forming assay. The isolation of

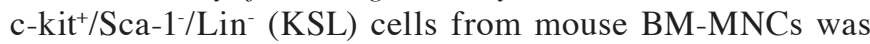
performed as previously described $(14,25,26)$. The numbers of small and large colonies, i.e., primitive endothelial progenitor cell colonies with clusters of homogeneous small immature cells and definitive endothelial progenitor cell colonies with clusters of large spindle-shaped differentiated cells were counted following the culture of KSL cells (500 cells/35-mm dish) for 10 days in a methyl cellulose-containing medium (M3236; (StemCell Technologies, Inc.) with $20 \mathrm{ng} / \mathrm{ml}$ stem cell factor (Sigma-Aldrich; Merck KGaA), $50 \mathrm{ng} / \mathrm{ml}$ VEGF, $20 \mathrm{ng} / \mathrm{ml}$ interleukin-3 (R\&D Systems, Inc., Minneapolis, MN, USA), $50 \mathrm{ng} / \mathrm{ml} \mathrm{bFGF}, 50 \mathrm{ng} / \mathrm{ml} \mathrm{EGF,} 2 \mathrm{U} / \mathrm{ml}$ heparin, $30 \% \mathrm{FBS}$ and antibiotics $(100 \mathrm{U} / \mathrm{ml}$ penicillin and $100 \mathrm{mg} / \mathrm{ml}$ streptomycin; Thermo Fisher Scientific, Inc.). The CFUs were counted by blinded investigators 12 days after seeding by visual inspection with an inverted microscope at x40 magnification. The expression of additional endothelial marker genes, such as cluster of differentiation (CD)31, VEGFR2 [also known as fetal liver kinase 1 (Flk1)], von Willebrand factor, vascular endothelial cadherin and eNOS in small and large CFUs was conducted as previously described (14).

Cell counting kit-8 (CCK-8) assay. EPCs $\left(3 \times 10^{3}\right)$ were cultured on 96 -well plates. Following 24 or $36 \mathrm{~h}$ incubation in a hypoxic chamber, CCK-8 solution (Dojindo Molecular Technologies, Inc., Rockville, MD, USA) was added to each 
well and incubated for another $2 \mathrm{~h}$ at $37^{\circ} \mathrm{C}$. Absorbance of the plate was measured with a microplate reader (Infinite M200 Pro; Tecan Group, Ltd., Mannedorf, Switzerland) at $540 \mathrm{~nm}$. Three replicate wells were used for each analysis.

Migration assay of early EPCs. A migration assay of early EPCs was performed as previously reported (27). Briefly, using a modified Boyden chamber, 1 day-starved early EPCs $\left(1 \times 10^{4}\right)$ were seeded onto a 24-well Transwell membrane and treated with VEGF (10 ng/ml) or stromal cell-derived factor (SDF)-1 $\alpha$ $(100 \mathrm{ng} / \mathrm{ml})$ in the bottom chamber for $6 \mathrm{~h}$. Migrated EPCs were stained with hematoxylin and eosin, and then counted using a CKX41SF microscope (Olympus Corporation, Tokyo, Japan).

Matrigel tube formation assay. Early EPCs (1:1; $1 \times 10^{4}$ cells/100 $\mu 15 \%$ FBS/EGM-2) were incubated with $0.4 \mu \mathrm{g} / \mathrm{ml}$ DiI-Ac-LDL (Biomedical Technologies Inc., Stoughton, MA, USA) for $4 \mathrm{~h}$ at $37^{\circ} \mathrm{C}$ and then cocultured with human umbilical vein endothelial cells (HUVECs; BD Biosciences, San Jose, CA, USA) on a 96-well culture plate coated with Matrigel ${ }^{\circledR}$ (BD Biosciences) for $30 \mathrm{~min}$ at $37^{\circ} \mathrm{C}$. Plates were examined for tube formation following incubation for $8 \mathrm{~h}$. The tube lengths and the number of incorporated DiI-expressing EPCs per HPF were counted (n=3/group) using a microscope (Olympus Corporation) at x200 magnification.

Enzyme-linked immunosorbent assay (ELISA). The amount of VEGF protein secreted by EPCs into the medium was determined using a VEGF ELISA kit (cat. no. MWV00; R\&D Systems). The cells were cultured in 6-well plates until they reached $80-90 \%$ confluence and the amount of VEGF was quantified using a microplate reader (Infinite M200 Pro; Tecan Group, Ltd.)

Reverse transcription-quantitative polymerase chain reaction (RT-qPCR) and semi-quantitative PCR. Total RNA was isolated from mouse early EPCs using TRIzol (Invitrogen; Thermo Fisher Scientific, Inc.) and RT-qPCR was performed as previously reported (28). The semi-quantitative PCR was performed using AccuPower PCR premix (Bioneer Corporation, Daejeon, Korea). The PCR conditions were as follows: 28 cycles of denaturation $\left(94^{\circ} \mathrm{C} / 1 \mathrm{~min}\right)$, annealing $\left(60^{\circ} \mathrm{C} / 1 \mathrm{~min}\right)$, extension $\left(72^{\circ} \mathrm{C} / 1 \mathrm{~min}\right)$ and final extension $\left(72^{\circ} \mathrm{C} / 10 \mathrm{~min}\right)$. The primer sequences for the genes tested are shown in Table I. PCR products were separated on $1.5 \%$ agarose gels in $1 \mathrm{X}$ TAE buffer, stained with ethidium bromide and visualized under UV light.

Western blot analysis. EPCs were lysed with ProPrep protein extraction solution (Intron Biotechnology, Inc., Seoul, Korea), and the protein concentrations of the lysates were measured using a Pierce BCA protein assay kit (Thermo Fisher Scientific, Inc.). Proteins (50 $\mu \mathrm{g} /$ lane) were separated by $10 \%$ SDS-PAGE and transferred to a nitrocellulose membrane (Whatman; GE Healthcare Life Sciences). The membrane was blocked with $5 \%$ non-fat skimmed milk in Tris-buffered saline containing $0.1 \%$ Tween-20, for $30 \mathrm{~min}$ at room temperature. The membrane was incubated with primary antibodies at $4^{\circ} \mathrm{C}$ overnight, and then with secondary antibodies conjugated with horseradish
Table I. Primer sequences for polymerase chain reaction.

\begin{tabular}{lll}
\hline Gene & Direction & \multicolumn{1}{c}{ Primer sequence } \\
\hline SDF-1 $\alpha$ & Forward & 5'-CTGTAGCCTGACGGACCAAT-3' \\
& Reverse & 5'-CCATTCTACAGGAGGCCAAA-3' \\
CXCR4 & Forward & 5'-AGCCTCTGCTCATGGAGTTG-3' \\
& Reverse & 5'-GCCAAGTTCAAAAGCTCTGC-3' \\
VEGF & Forward & 5'-GGGCAGAGCTGAGTGTTAGC-3' \\
& Reverse & 5'-TCTCCCAGATCGGTGACAGT-3' \\
Flk1 & Forward & 5'-TTCCCCCCTGGAAATCCT-3' \\
& Reverse & 5'-ACAGACCCGGCCAAACAA-3' \\
eNOS & Forward & 5'-CGGCATCACCAGGAAGAAGA-3' \\
& Reverse & 5'-CATGAGCGAGGCGGAGAT-3' \\
$\beta$-actin & Forward & 5'-AAGTCCCTCACCCTCCCAAAAG-3' \\
& Reverse & 5'-AAGCAATGCTGTCACCTTCCC-3' \\
\hline
\end{tabular}

SDF, stromal cell-derived factor; CXCR4, C-X-C chemokine receptor type 4; VEGF, vascular endothelial growth factor; Flk1, fetal liver kinase (VEGF receptor 2); eNOS, endothelial nitric oxide synthase.

peroxidase for $1 \mathrm{~h}$ at room temperature. Finally, the membrane was visualized using the West Pico Chemiluminescent Substrate (Pierce; Thermo Fisher Scientific, Inc.). The quantification was performed using ImageJ software (version 1.52a; National Institutes of Health, Bethesda, MD, USA). Primary antibodies used for western blot analysis were as follows: VEGF (1:500; cat. no. sc-152; Santa Cruz Biotechnology, Inc., Dallas, TX, USA), VEGFR2 (1:1,000; cat. no. 2479), phospho (P)-VEGFR2 (1:500; cat. no. 2478), extracellular signal-regulated kinase (ERK; 1:1,000; cat. no. 9102), P-ERK (1:1,000; cat. no. 9101), AKT (1:1,000; cat. no. 4691), P-AKT (1:1,000; cat. no. 9271), Jun N-terminal kinase (JNK: 1:1,000; cat. no. 9252), P-JNK (1:1,000; cat. no. 9251), eNOS (1:1,000; cat. no. 9586), P-eNOS (1:1,000; cat. no. 9571) (all from Cell Signaling Technology, Inc., Danvers, MA, USA), HIF-1 $\alpha$ (1:500; cat. no. 610958; BD Biosciences), RUNX3 (1:500; cat. no. 40278; Abcam, Cambridge, UK) and $\alpha$-tubulin (1:1,000; cat. no. 3873; Cell Signaling Technology, Inc.). HRP-linked secondary antibodies were purchased from Cell Signaling Technology Inc. (1:5000; cat. nos. 7076 and 7074).

Flow cytometric analysis. To count the number of circulating EPCs, MNCs isolated from PB were stained with fluorescein isothiocyanate (FITC)-conjugated anti-CD34 monoclonal antibody (1:100; cat. no. GTX20218; GeneTex, Inc., Irvine, CA, USA) and phycoerythrin-conjugated anti-VEGFR2 monoclonal antibody (1:100; cat. no. 555308; BD Biosciences) for $1 \mathrm{~h}$ at room temperature. The cells were washed with PBS three times. A FACS flow cytometer (FACSAria flow cytometer; BD Biosciences) was used to detect the double-positive fluorescent cells using FACSexpress Software (version 4; De Novo Software, Glendale, CA, USA).

Mouse hindlimb ischemia model. A unilateral mouse hindlimb ischemia model was established as previously described (29). Briefly, WT and $\mathrm{Rx} 3^{+/-}$mice were anesthetized 
with $2 \%$ Avertin $(250 \mathrm{mg} / \mathrm{kg})$ by intraperitoneal injection ( $\mathrm{n}=3 \mathrm{mice} / \mathrm{group}$ ). The proximal and distal portions of the femoral artery and the distal portion of the saphenous artery were ligated. The arteries and all side branches were dissected free and excised. A laser Doppler perfusion imaging system (PeriScan PIM II; Perimed AB, Järfälla, Sweden) was used to measure hindlimb blood perfusion immediately following surgery and at the end of the study on day 14 . To avoid the influence of ambient light and temperature, the results were expressed as the ratio between perfusion in the left (ischemic) versus right (non-ischemic) limbs.

In vivo tumor allograft experiment. Lewis lung carcinoma (LLC; American Type Culture Collection, Manassas, VA, USA) cells $\left(2 \times 10^{5}\right)$ were injected subcutaneously into the right and left flanks of 6-week old WT or $\mathrm{Rx} 3^{+/-}$mice on day 0 ( $\mathrm{n}=4$ mice/group). Tumor growth was measured with a caliper every other day from day 9 , and the tumor volume was calculated using the following formula: Volume $\left(\mathrm{cm}^{3}\right)=$ height $\mathrm{x}$ length $\mathrm{x}$ depth $(\mathrm{cm})$. Tumor tissues were removed at day 14 and fixed with $4 \%$ paraformaldehyde.

Immunohistochemistry. LLC-derived tumor tissues from the allograft experiment and hindlimb muscle tissues from the mice in the ischemia experiment were removed at day 14 and fixed with $4 \%$ paraformaldehyde. Frozen blocks were made at $-26^{\circ} \mathrm{C}$ and cut into $10-\mu \mathrm{m}$ sections, blocked with $5 \%$ goat serum (Abcam) in PBS containing 0.03\% Triton X-100 for $1 \mathrm{~h}$, and then incubated for $3 \mathrm{~h}$ at room temperature with anti-CD34 (cat. no. 553731), anti-CD31 (cat. no. 553370) (both from BD Pharmingen; BD Biosciences) and anti-VEGFR2 (cat. no. 2479; Cell Signaling Technology, Inc.) primary antibodies, followed by Alexa Fluor 488 anti-rabbit IgG and Alexa Fluor 594 anti-rat IgG (Thermo Fisher Scientific, Inc.) secondary antibodies for $1 \mathrm{~h}$ at room temperature with protection from light. After washing with PBS, the samples were mounted with mounting medium containing DAPI (Vector Laboratories, Inc., Burlingame, CA, USA), and observed under a confocal microscope (Leica Microsystems, Inc., Buffalo Grove, IL, USA). The quantitation was acquired using ImageJ software.

Statistical analysis. SPSS software was used for all statistical analyses. Differences among experimental groups were compared using one-way analysis of variance with the Newman-Keuls post hoc test. $\mathrm{P}<0.05$ was considered to indicate a significant difference. Results are presented as the mean \pm standard deviation.

\section{Results}

Runx3 knockout enhances the differentiation of EPCs. Since Runx 3 homozygote knockout $\left(\mathrm{Rx}^{--}\right)$mice die soon after birth (24), $\mathrm{Rx}^{+/-}$mice were used for the isolation of MNCs from adult BM. To identify the role of Runx3 in EPC differentiation, the $\mathrm{BM}$-derived $\mathrm{MNCs}$ isolated from $\mathrm{R} 3^{+/}$ mice were differentiated into EPCs. Western blotting results confirmed that Runx3 was expressed in the early EPCs from WT mice but repressed in those from $\mathrm{Rx} 3^{+/}$mice (Fig. 1A). Using the EPC colony-forming assay, the self-renewal and differentiation abilities of EPCs were investigated via the detection of two differently differentiated EPCs in terms of EPC hierarchy. Colonies formed from relatively small and rounded cells are known as small EPC CFUs, which exhibit the characteristics of primitive EPCs, including high proliferative activity and immature properties, and colonies formed from spindle-shaped cells are known as large EPC CFUs, which exhibit late or mature EPC characteristics, including as improved tube formation ability and neovascularization (13). The numbers of small and large EPC CFUs were observed to be significantly increased in the $\mathrm{Rx} 3^{+/-}$mice compared with the WT mice (Fig. 1B and C). These results suggest that the deletion of Runx 3 is associated with the increased self-renewal and differentiation capacity of EPCs.

In vitro vasculogenic activity is increased in $R \times 3^{+/-}$EPCs. Adherent MNC cells that were cultured for 7 days, with the removal of non-adherent BM-MNCs after 3 days, changed their morphology from round to spindle-like but did not form colonies in the presence of endothelial cell growth supplements. These cells were characterized as early EPCs $(15,16)$ and exhibited Dil-Ac-LDL uptake, isolectin B4 binding, expression of CD34 (a HSC marker) and VEGFR2 (Flk1, an endothelial cell marker) as in a previous study (21).

The growth rate of early EPCs derived from $\mathrm{Rx} 3^{+/}$MNCs was significantly increased compared with that of early EPCs derived from WT MNCs under normoxia and hypoxia (Fig.2A). As VEGF and SDF-1 $\alpha$ serve important roles in the regulation of various cellular functions of EPCs, such as migration and homing to injured tissues $(16,30)$, a Boyden chamber migration assay using early EPCs in the presence of VEGF or SDF-1 $\alpha$ was performed in the present study. VEGF or SDF-1 $\alpha$ treatment induced the migration of EPCs, and the number of migrated cells was significantly increased in $\mathrm{Rx}^{+/-}$EPCs compared with WT EPCs (Fig. 2B). To evaluate the ability of EPCs to differentiate into ECs and form tubes, a tube formation assay was performed on a Matrigel matrix using a 1:1 mixture of DiI-Ac-LDL-labeled EPCs and HUVECs. The tube formation ability was monitored using tube length measurements. As shown in Fig. 2C, the capillary networks developed by $\mathrm{Rx} 3^{+/}$EPCs and HUVECs were more pronounced than those formed by WT EPCs and HUVECs. The total tube length and number of EPCs incorporated into the tubes were significantly increased in the $\mathrm{R} \times 3^{+/}$group compared with the WT group. These results suggest that the absence of Runx 3 increases the neovessel-forming differentiation ability of EPCs.

Expression of growth factors and their receptors involved in

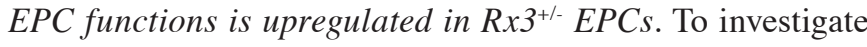
whether the increased vessel formation ability of EPCs with Runx3 deletion is due to increased vasculogenic gene expression patterns in EPCs, the mRNA expression levels of growth factors and their receptors involved in vasculogenesis were analyzed. RT-qPCR revealed that the mRNA expression levels of VEGF, SDF-1 $\alpha, \mathrm{C}-\mathrm{X}-\mathrm{C}$ chemokine receptor type 4 (CXCR4) and eNOS were significantly upregulated in $\mathrm{Rx}^{+/-}$EPCs compared with WT EPCs (Fig. 3A), while a significant increase in VEGFR2 (Flkl) mRNA expression was detected. To confirm these results, the phosphoinositide-3 kinase (PI3K) and mitogen-activated protein kinase (MAPK) signaling pathways that are activated by VEGFR2 were 
A

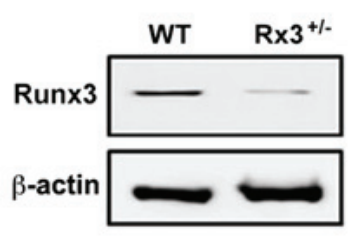

B

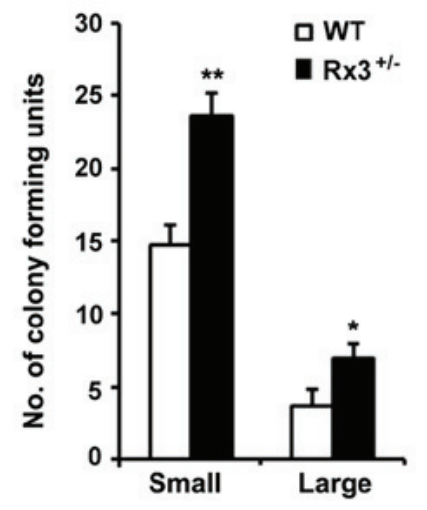

C
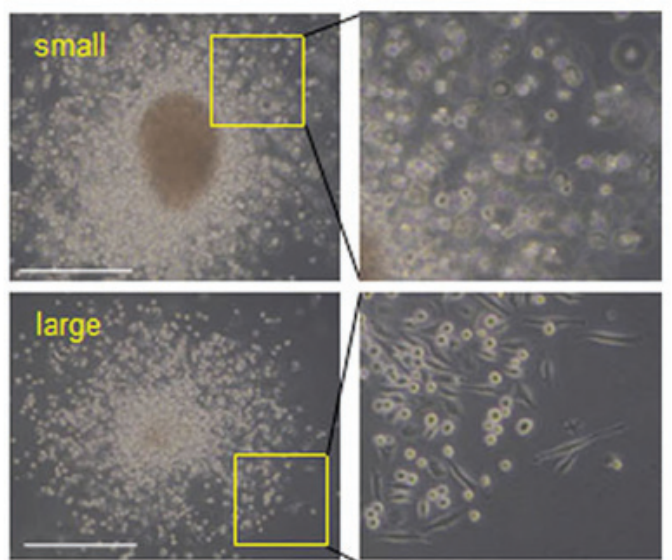

Figure 1. Heterozygous deletion of Runx 3 enhances the differentiation of EPCs. (A) Expression of Runx3 was determined by western blot analysis in the BM-derived early EPCs of WT and Rx $3^{+/-}$mice. (B) The c-kit $/$Sca- $1^{-} /$Lin $^{-}$cells isolated from WT and $\mathrm{Rx} 3^{+/-}$mice BM were seeded in methylcellulose-containing media and the numbers of CFUs were counted on day 12 after seeding ( $\mathrm{n}=4 /$ group; three independent experiments). ${ }^{*} \mathrm{P}<0.05$, ${ }^{* *} \mathrm{P}<0.01 \mathrm{vs}$. WT control (C) Representative small and large CFUs. Enlarged images of the boxed regions are shown in the right panels. Scale bar, $500 \mu \mathrm{m}$. BM, bone marrow; Runx3, runt-related transcription factor 3; Rx $3^{+/}$, Runx3 heterozygous; WT, wild-type; EPC, endothelial progenitor cell; CFU, colony-forming unit.

A

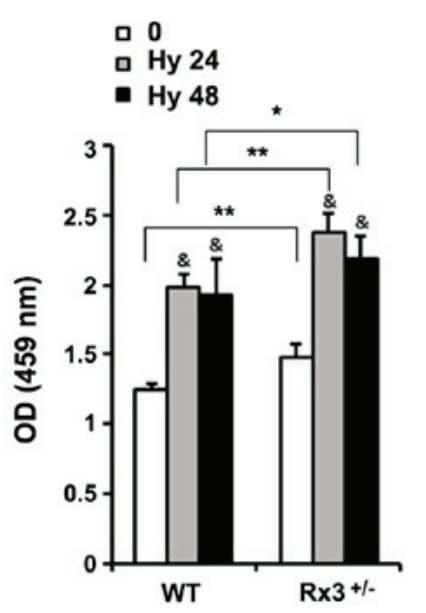

B
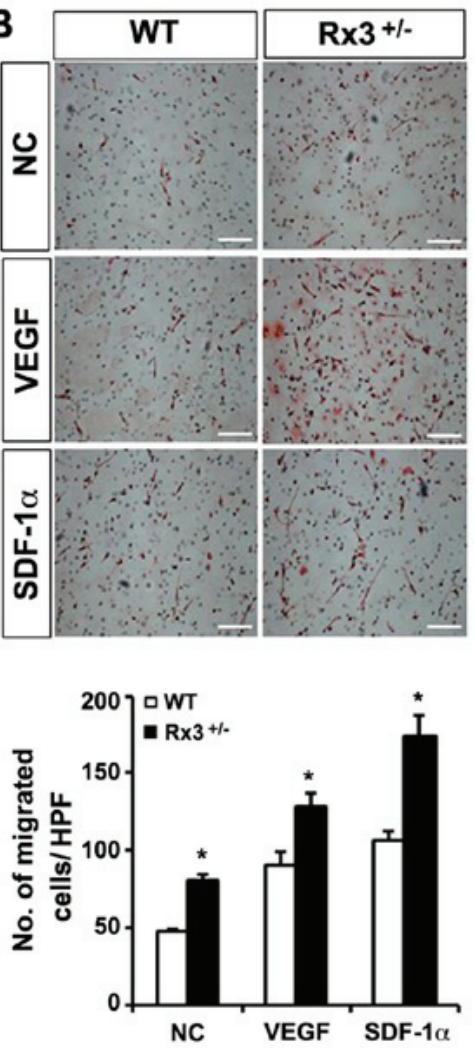
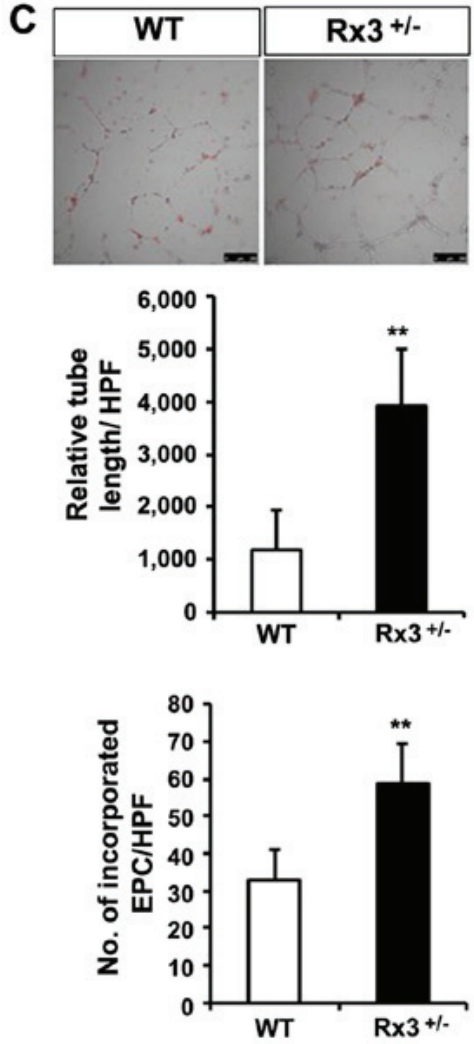

Figure 2. Enhanced function of EPCs by heterozygous deletion of Runx3 in response to hypoxia and angiogenic factors. (A) The cell proliferation ability of early EPCs under hypoxic conditions for 24 or $48 \mathrm{~h}$ was measured by CCK- 8 assay ( $\mathrm{n}=4 /$ group; three independent experiments). ${ }^{\&} \mathrm{P}<0.01 \mathrm{vs}$. normoxic control; ${ }^{*} \mathrm{P}<0.05,{ }^{* *} \mathrm{P}<0.01$ as indicated. (B) Migration assay with early EPCs treated with VEGF (10 ng/ml) or SDF- $1 \alpha(100 \mathrm{ng} / \mathrm{ml})$ was performed. "P<0.05 vs. WT control. ( $\mathrm{n}=4$ /group; three independent experiments). Scale bar, $250 \mu \mathrm{m}$. (C) Early EPCs stained with 3,3'-DiI-labeled acetylated low-density lipoprotein were co-cultured with human umbilical vein endothelial cells on a Matrigel matrix for $8 \mathrm{~h}$. The tube length was measured and the number of incorporated DiI-expressing EPCs per HPF was counted ( $\mathrm{n}=3$ /group; three independent experiments). Representative images are shown in the upper panel. ${ }^{* *} \mathrm{P}<0.01 \mathrm{vs}$. WT control. ( $\mathrm{n}=4 /$ group; three independent experiments). Scale bar, $250 \mu \mathrm{m}$. EPC, endothelial progenitor cell; Runx3, runt-related transcription factor 3; $\mathrm{Rx}^{+/-}$, Runx3 heterozygous; CCK-8, Cell counting kit-8; DiI, dioctadecylindocarbocyanin; WT, wild-type; NC, negative control; VEGF, vascular endothelial growth factor; SDF, stromal cell-derived factor; 0, normoxia; Hy 24, hypoxia 24 h; Hy 48, hypoxia 48 h; OD, optical density; HPF, high-power field.

investigated. VEGFR2 mRNA expression was not altered with Runx3 deletion, but the phosphorylation of VEGFR2 was observed to be significantly increased in $\mathrm{Rx} 3^{+/}$EPCs compared with WT EPCs (Fig. 3B). As PI3K and MAPKs, including JNK and ERK1/2, are downstream molecules for CXCR4/SDF-1 $\alpha(31,32)$ as well as VEGF/VEGFR2 signaling pathways (33), the activation of Akt, JNK and ERK1/2 in $\mathrm{Rx} 3^{+/}$EPCs was examined. The phosphorylation levels of Akt, 


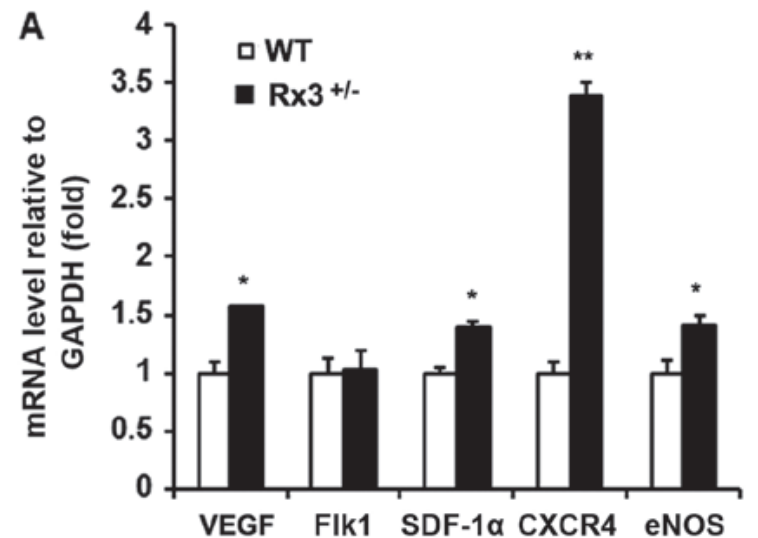

C
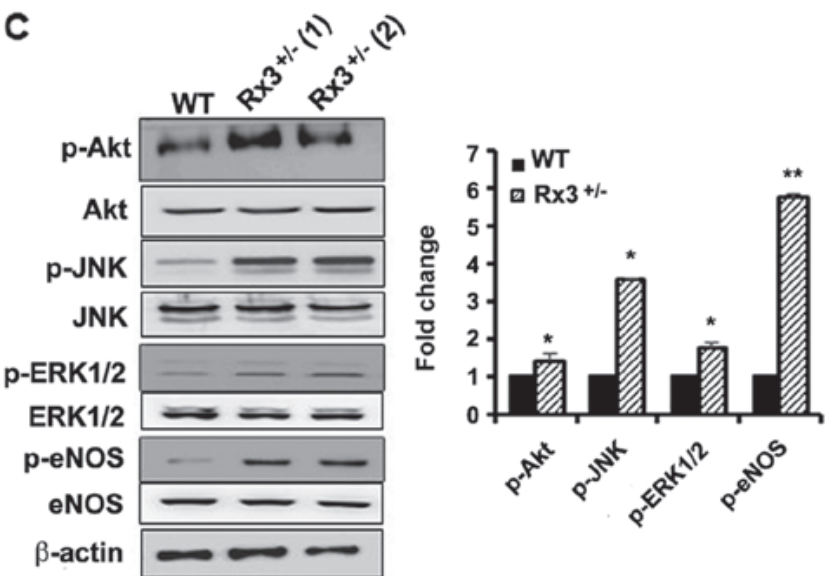
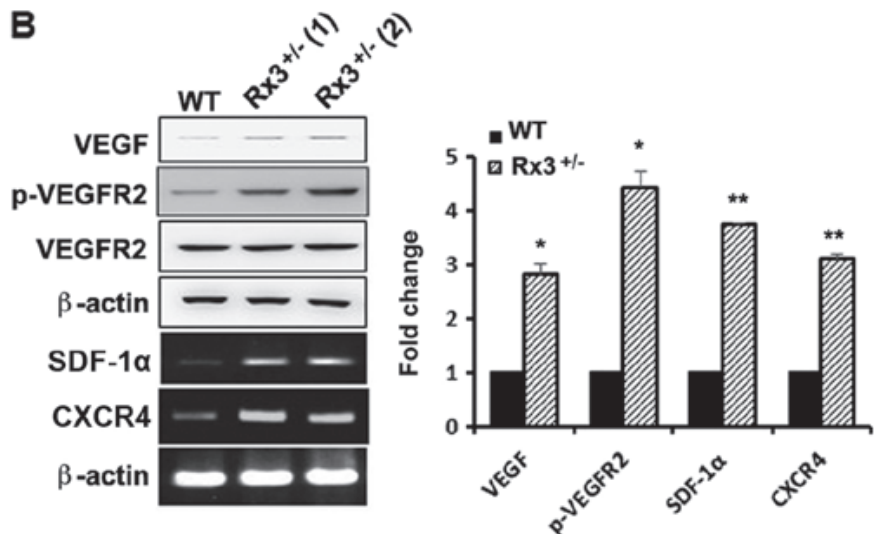

D

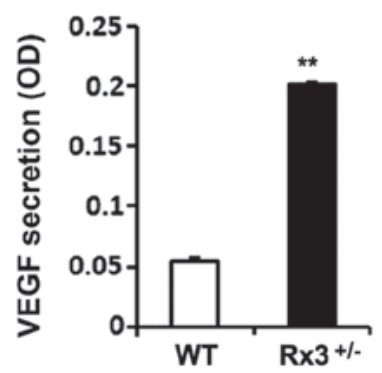

Figure 3. Heterozygous deletion of Runx3 activates VEGF and SDF-1 $\alpha$ signaling pathways. (A) Detection of total RNA extracted from early EPCs using RT-qPCR. Data are the mean \pm standard deviation of three independent experiments. (B) Western blot analysis of VEGF, p-VEGFR2 and VEGFR2, and analysis of $S D F-1 \alpha$ and $C X C R 4$ mRNA levels using semi-quantitative RT-PCR analysis. VEGF, $S D F-1 \alpha$ and $C X C R 4$ are normalized to $\beta$-actin while p-VEGFR2 and VEGFR2 are normalized to $\beta$-actin and presented as the p-VEGFR2/VEGFR2 ratio. (C) Activation of Akt, JNK, ERK1/2 and eNOS in early EPCs from WT and $\mathrm{Rx}^{+/-}$mice was determined using western blot analysis. (D) Secreted VEGF was determined by ELISA in the serum-free media collected from WT and Rx3 ${ }^{+/}$early EPCs. "P<0.05, ${ }^{* *} \mathrm{P}<0.01$ vs. WT. Runx3, runt-related transcription factor 3 ; Rx3 $3^{+/}$, Runx3 heterozygous; WT, wild-type; VEGF, vascular endothelial growth factor; Flk1, fetal liver kinase 1, also known as VEGFR2; VEGFR2, VEGF receptor 2; SDF, stromal cell-derived factor; CXCR4, C-X-C chemokine receptor type 4; eNOS, endothelial nitric oxide synthase; EPC, endothelial progenitor cell; RT-(q)PCR, reverse transcription-(quantitative) polymerase chain reaction; p, phospho; JNK, Jun N-terminal kinase; ERK1/2, extracellular signal-regulated kinase1/2; OD, optical density.

JNK and ERK1/2 were significantly increased in $\mathrm{Rx} 3^{+/}$EPCs compared with WT EPCs (Fig. 3C). The activation of eNOS is positively controlled by Akt through the phosphorylation of Ser1178 (34) and results in the generation of NO that serves a crucial role in vessel vasodilation and vasculogenesis (35). Thus, the amount of the activated form of eNOS was evaluated. The activated form of eNOS was observed to be significantly increased in $\mathrm{Rx} 3^{+/}$EPCs compared with WT EPCs (Fig. 3C). Furthermore, the secretion of VEGF from $\mathrm{Rx} 3^{+/-}$EPCs was confirmed to be significantly increased compared with that from WT EPCs (Fig. 3D). These results suggest that Runx3 knockout enhances vasculogenic signaling via the activation of VEGF/VEGFR2 and CXCR-4/SDF-1 $\alpha$ pathways.

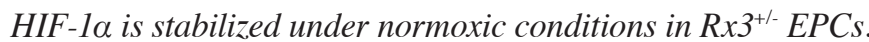
As VEGF, VEGFR(36),SDF-1 $\alpha$ and CXCR4 (37) are downstream targets of HIF-1 $\alpha$, the HIF-1 $\alpha$ protein levels in Rx $3^{+/-}$EPCs were measured under normoxic and hypoxic conditions. Compared with WT EPCs, HIF-1 $\alpha$ expression was increased 3 -fold in $\mathrm{Rx}^{+/-}$ EPCs under normoxic conditions (Fig. 4, lanes 1 and 2). Under hypoxic conditions, HIF-1 $\alpha$ was highly stabilized by 5 -fold in WT EPCs (Fig. 4, lane 1 and lane 3), whereas in $\mathrm{Rx}^{+/-} \mathrm{EPCs}$,
HIF-1 $\alpha$ was more increased by 2.7-fold (Fig. 4, lanes 2 and 4), suggesting that Runx 3 destabilizes HIF-1 $\alpha$ protein.

Mobilization into PB circulation is reduced in Rx $3^{+/-}$EPCs. The mobilization of EPCs from the BM into the peripheral circulation, resulting in circulating EPCs (CEPCs), is a critical step during the process of neovascularization at ischemic sites (35). Therefore, the percentage and number of CEPCs in the PB were investigated via the flow cytometric detection of the EPC markers CD34 and VEGFR2. The percentage of EPCs in PB-MNCs was found to be significantly increased in $\mathrm{R} \times 3^{+/-}$mice $(1.1 \pm 0.12 \%)$ compared with WT mice $(0.5 \pm 0.08 \%$; Fig. 5A and B). Furthermore, the number of EPCs in the PB of $\mathrm{Rx}^{+/-}$mice $(1,603.2 \pm 38.12 \mathrm{EPCs} / \mu \mathrm{l})$ was 3 -fold higher than that of WT mice (497.1 $\pm 32.74 \mathrm{EPCs} / \mu 1$; Fig. 5C). The results indicate that, consistent with the expression patterns of vasculogenic signaling molecules, the mobilization of EPCs into the $\mathrm{PB}$ is also stimulated by the knockdown of Runx3.

Repair of blood flow in hindlimb-ischemia and tumor tissue infiltration of EPCs of $R \times 3^{+/-}$mice. As the aforementioned results reveal that the haploinsufficient deletion of Runx3 

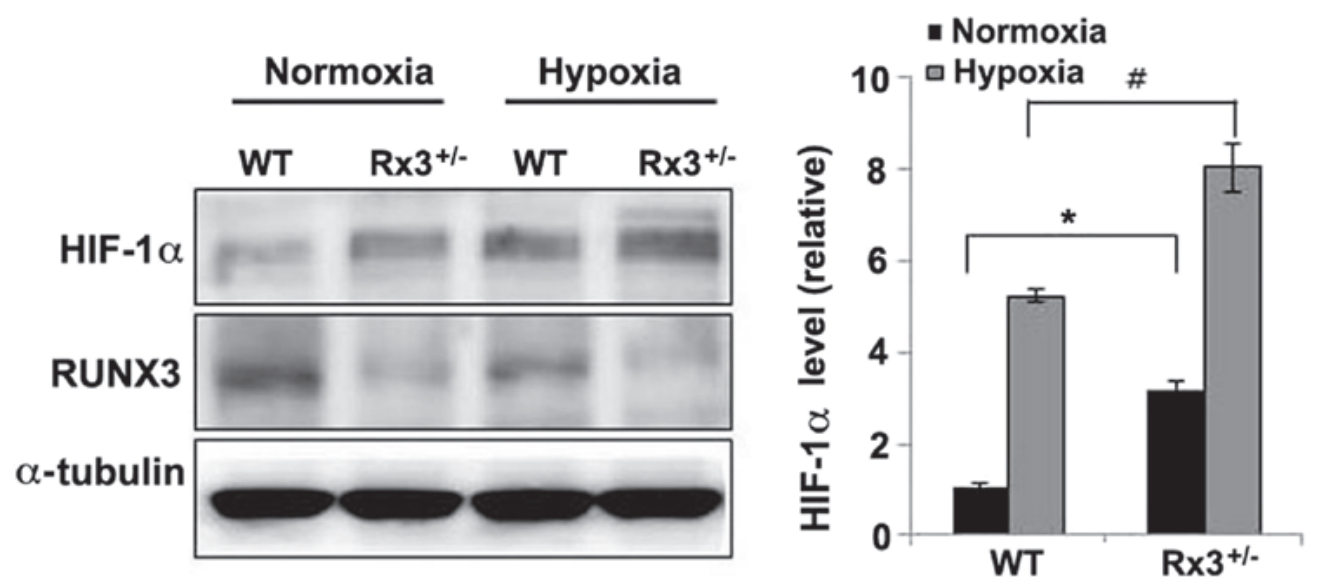

Figure 4. Heterozygous deletion of Runx3 increases HIF-1 $\alpha$ expression in cultured EPCs. Early EPCs from WT or heterozygous Runx3-deleted mice were cultured in normoxic or hypoxic conditions for $8 \mathrm{~h}$. Whole cell extracts were subjected to western blot analysis of HIF-1 $\alpha$ and RUNX3. ${ }^{*}<0.05$, Runx3, runt-related transcription factor 3; Rx $3^{+/}$, Runx3 heterozygous; WT, wild-type; HIF, hypoxia-inducible factor; EPC, endothelial progenitor cell.
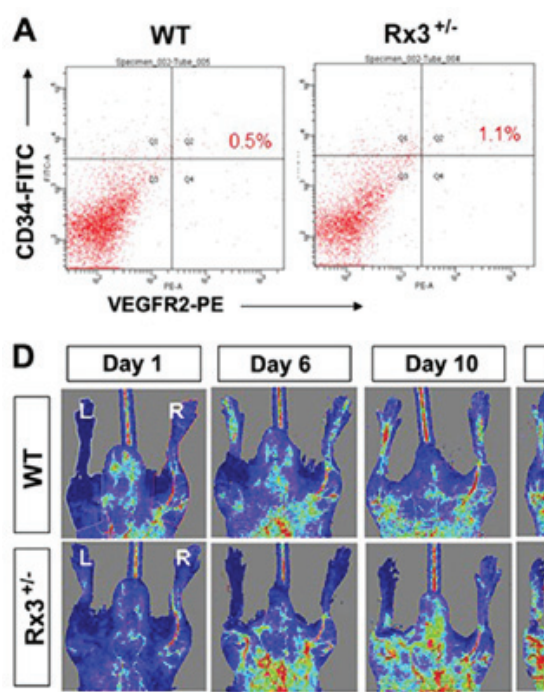

B

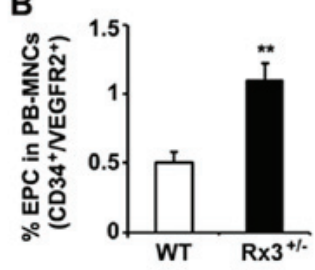

E

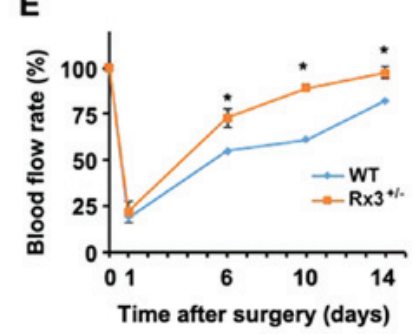

C
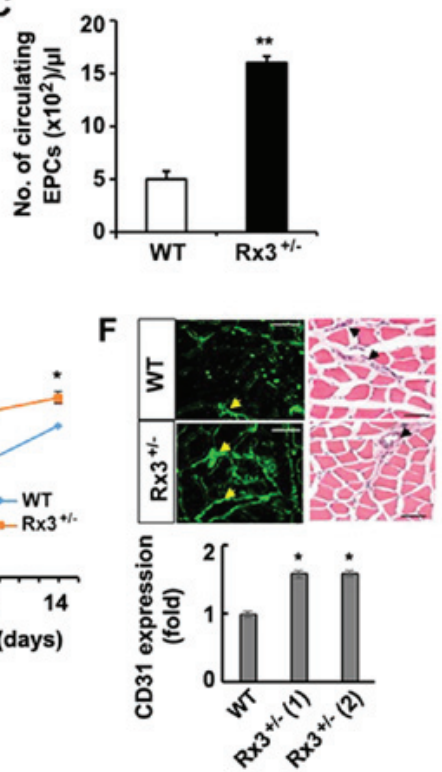

G

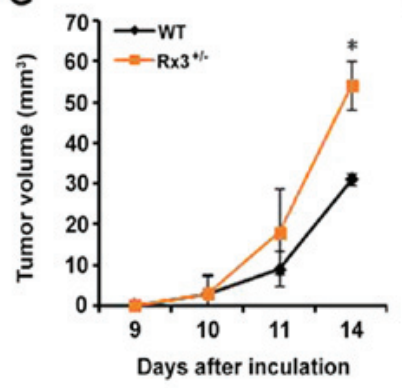

H VEGFR2

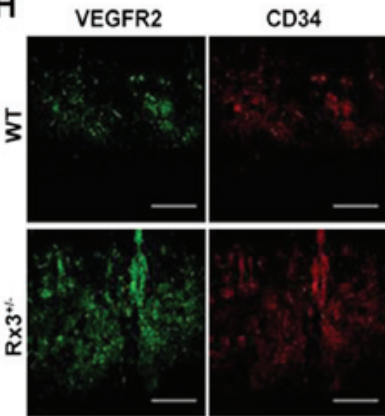

DAPI

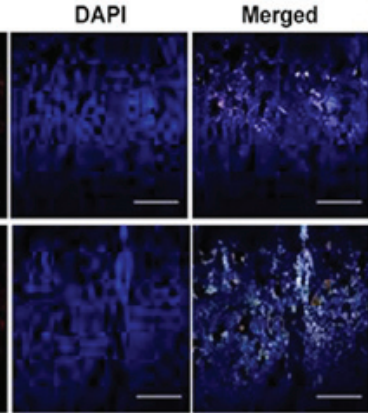

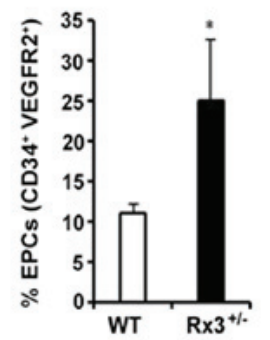

Figure 5. Heterozygous deletion of Runx 3 increases the mobilization of EPCs from the bone marrow to the peripheral circulation and ischemic hindlimb. (A) Mononuclear cells were isolated using the density gradient method and stained with a FITC-conjugated anti-CD34 antibody and PE-conjugated anti-VEGFR2 antibody. Flow cytometric analysis was performed to detect CD34 $4^{+}$VEGFR2 ${ }^{+}$circulating EPCs. (B) Percentage and (C) total numbers of circulating EPCs were counted in 10,000 peripheral blood cells. ${ }^{* *} \mathrm{P}<0.01$ vs. WT. (D) Representative images of the ischemic (L) and non-ischemic (R) hindlimbs immediately and 6,10 and 14 days after surgery. In the color-coded images, red indicates normal perfusion, and blue indicates a marked reduction in blood flow in the ischemic hindlimb. (E) Blood flow rate was recovered in $\mathrm{Rx} 3^{+/}$mice compared with WT mice (n=3/group). "P $<0.05$ vs. WT. (F) CD31 regions (green fluorescence) in ischemic muscle detected using immunohistochemistry (left panels) were quantified, and representative images of hematoxylin and eosin stained tissue are shown (right panels). Arrow heads indicate the vessels. Scale bar, $50 \mu \mathrm{m}$. (G) LLC cells $\left(2 \times 10^{5}\right)$ were inoculated into bilateral flanks of WT or Runx3 heterozygous knockout mice (day 0 ) and the tumor size were measured at various time points. " $\mathrm{P}<0.05$ vs. WT $(\mathrm{n}=4)$. (H) Sectioned $(10 \mu \mathrm{m})$ tumor tissue from LLC-injected WT or heterozygous Runx3-deleted mice was immunostained with anti-VEGFR2 and anti-CD34 antibodies, which exhibit green and red fluorescence, respectively. Infiltrated EPCs (CD34 $/ \mathrm{VEGFR}^{+}$cells) were counted. ${ }^{*} \mathrm{P}<0.05$ vs. WT. Scale bar, $200 \mu \mathrm{m}$. Runx3, runt-related transcription factor 3; Rx3 ${ }^{+/}$, Runx3 heterozygous; WT, wild-type; EPC, endothelial progenitor cell; FITC, fluorescein isothiocyanate; PE, phycoerythrin; CD, cluster of differentiation; VEGFR2, vascular endothelial growth factor receptor 2; L, left; R, right; LLC, Lewis lung carcinoma. 
increased EPC function (Figs. 1-4), and a previous study demonstrated that RUNX3 inhibits the stability of HIF-1 $\alpha$ (20), a main transcription factor of angiogenesis and vasculogenesis in hypoxia, angiogenesis in $\mathrm{Rx} 3^{+/}$mice was investigated in vivo using a hindlimb-ischemia model. Compared with WT mice, blood flow was significantly increased in $\mathrm{Rx} 3^{+-}$mice from day 6 after ligation of the hindlimb artery and vein. At 10 and 14 days post-ligation, the blood flow rate in the hindlimb and foot was completely recovered in $\mathrm{Rx}^{+/-}$mice (Fig. 5D and E). When the hindlimb muscle was analyzed by immunohistochemistry using an anti-CD31 antibody, the microvessel density was observed to be markedly increased in the $\mathrm{Rx} 3^{+/-}$mice compared with the WT mice (Fig. 5F). Furthermore, in an LLC allograft model, the tumor volume in $\mathrm{Rx} 3^{+/}$mice was significantly larger than that in WT mice (Fig. 5G) and the EPC population $\left(\mathrm{CD} 34^{+} / \mathrm{VEGFR} 2^{+}\right.$cells) in the tumor mass was $\sim 2.5$-fold greater in the $\mathrm{Rx} 3^{+/-}$mice compared with the WT mice (Fig. 5H). These results suggest that the mobilization of EPCs into the tumor vessels is increased in $\mathrm{Rx} 3^{+/-}$mice.

\section{Discussion}

The present study suggests that Runx 3 may be an inhibitor of EPC function and the differentiation of BM-MNCs into EPCs. EPCs, first identified in human PB (38), are a small population of circulating or BM-derived MNCs, which are incorporated into sites of neovascularization, and contribute to vascular repair in ischemic tissues by increasing the expression of cytokines, growth factors and/or hormones through autocrine, paracrine and/or endocrine systems (39); this is the process of postnatal vasculogenesis. Thus, EPCs are considered to have potential value in therapeutic vasculogenesis for various ischemic diseases (40). With the same properties as EPCs, they could also be incorporated into hypoxic tumor regions for neovessel formation. Thus, they may be a target for the molecular inhibition of tumor vasculature.

RUNX3, a tumor suppressor, activates the TGF- $\beta$ signaling pathway and inhibits angiogenesis via the suppression of VEGF transcription (41) and by reducing HIF-1 $\alpha$ stability (20). Since VEGF and HIF-1 $\alpha$ are crucial factors for vasculogenesis, the present study investigated whether RUNX3 influences the differentiation of EPCs and vasculogenesis. Similar to RUNX3, RUNX1 is also known to function as a tumor suppressor because its mutation results in the development of leukemia (23). As RUNX1 is required for hematopoiesis, a RUNX1 null mutation results in defective hematopoiesis, which leads to the impairment of angiogenesis in the developing embryo (42), suggesting that RUNX1 is required for embryonic vasculogenesis via the modulation of hematopoiesis. However, a transcriptional activity assay in a previous study revealed that VEGF gene expression is inhibited by RUNX1 but increased by an acute myeloid leukemia (AML)/RUNX1 fusion protein (AML/ETO) (43). Therefore, the function of RUNX1 in vessel formation is different between embryogenesis and leukemia development. As RUNX3 and RUNX1 have similar properties in a number of biological responses, the observation that loss of Runx 1 function in zebrafish embryos leads to defects in hematopoiesis and vasculogenesis (44) suggests that Runx3 deletion may affect hematopoiesis and/or vasculogenesis.
However, RUNX1 cross-regulates the expression of RUNX3 in lymphoid cells (45), further suggesting that the role of Runx3 in the differentiation of BM-HSCs might be distinct from that of Runx1. A genomic study demonstrating different gene expression patterns between early EPCs (small EPCs in the present study) and outgrowth ECs (OECs having similar properties as large EPCs in the present study) revealed that Runx1 is expressed in early EPCs (46). Early EPCs (small EPCs) exhibit more premature and undifferentiated properties in a differentiation hierarchy relative to large EPCs. The present study demonstrated that in small and large EPC CFUs, Runx3 knockout cells formed a greater number of CFUs than did WT cells, suggesting that Runx3 has an inhibitory role in the early and late stages of EPC differentiation from BM stem cells. Runx3 regulates the differentiation of BM-derived dendritic cells by the TGF- $\beta$ signaling pathway (47). Dendritic cell maturation is essential for the immune response; however, the differentiation process of EPCs may differ from those of other myeloid and lymphoid cells. Runx3 is required for the silencing of CD4 during T-cell lineage decisions $(48,49)$. Human $\mathrm{CD} 4^{+} \mathrm{HSCs}$ and several normal and malignant hematopoietic cell lines express RUNX3, suggesting that it plays a role in EPCs $(50,51)$. As the differentiation of EPCs from BM-MNCs and their mobilization or homing to injured or ischemic regions are dependent on VEGFR2 and CXCR4-SDF1 $\alpha$ signaling pathways $(52,53)$, Runx3 knockout may cause increased EPC differentiation, probably through VEGFR2 and CXCR4-SDF1 $\alpha$ pathways. As Runx3 destabilizes HIF-1 $\alpha$ and VEGF/VEGFR2 expression is induced by HIF-1 $\alpha$, it may be speculated that the heterozygous knockout of Runx3 increases HIF-1 $\alpha$ accumulation and thus VEGF/VEGFR2 expression.

The observation that CXCR4 and SDF1 $\alpha$ are also increased by HIF-1 $\alpha$ indicates a causative role in the increased EPC function induced by the heterozygous deletion of Runx3. The increase of EPC differentiation and function in heterozygous deletion of Runx3 may be explained by the tumor suppressive function of Runx3. Our results suggest that the stabilization of HIF-1 $\alpha$ in $\mathrm{Rx} 3^{+/}$EPCs increases VEGF/VEGFR2 and SDF-1 $\alpha / C X C R 4$ expression and their signaling pathways to enhance the differentiation of BM stem cells into EPCs. In a previous study, it was found that RUNX3 facilitates the degradation of HIF-1 $\alpha$ (54) by enhancing the interaction of PHDs with HIF-1 $\alpha$, which is a key inhibitor of hypoxia-induced VEGF secretion and angiogenesis in vitro and in vivo (20). Hypoxia downregulates RUNX3 expression and function (6), and is a strong inducer of EPC mobilization and homing via the enhanced expression of various cytokines, including eNOS and SDF1 $\alpha$. The present study indicates that Runx3 downregulation in ischemic regions results in hypoxia-induced cytokine expression and secretion which induces the recruitment of EPCs. Taken together, these results suggest that Runx3 functions to inhibit the differentiation of EPCs from BM-MNCs. Furthermore, Runx3 inhibits EPC functions, including self-renewal, migration, tube formation, as well as mobilization into the $\mathrm{PB}$ and homing to injured tissues. Therefore, Runx3 may totally inhibit vasculogenesis via the suppression of EPC differentiation and recruitment to ischemic tissues during the development of new vessels from BM. Therefore, it may be concluded that the inhibition 
of EPC differentiation and function by RUNX3 recovery or overexpression is a potential therapeutic strategy for the treatment of tumor progression and metastasis, but may inhibit tissue regeneration in ischemic diseases.

\section{Acknowledgements}

The authors would like to thank Dr Sarala Manandhar (Kyungpook National University, Daegu, Korea) for reading and editing the manuscript.

\section{Funding}

This study was supported by National Research Foundation grants from the Korean government (MSIP; NRF-2012R1A4A1028835, NRF-2013R1A2A2A01068868 and NRF-2017R1A2B3002227).

\section{Availability of data and materials}

The datasets used and/or analysed during the current study are available from the corresponding author on reasonable request.

\section{Authors' contributions}

SYC and SHY performed EPC isolation and analysis, cell culture, molecular analyses and in vivo experiments. DJL and SHL performed the isolation of EPCs and western blot analysis. KL, IHK and WL performed in vivo tumor allograft and IHC experiments with tumor tissue. SCB provided the Runx $3^{+-}$mice and analyzed the data. YML initiated the study, supervised the experiments, analysed data and wrote the manuscript.

\section{Ethics approval and consent to participate}

The animal experiments were by the Kyungpook National University Institutional Animal Care and Use Committee.

\section{Patient consent for publication}

Not applicable.

\section{Competing interests}

The authors declare that they have no competing interests.

\section{References}

1. Ito Y: Oncogenic potential of the RUNX gene family: 'overview'. Oncogene 23: 4198-4208, 2004.

2. Chuang LS, Ito K and Ito Y: RUNX family: Regulation and diversification of roles through interacting proteins. Int J Cancer 132 $1260-1271,2013$

3. Miyazono K, Maeda S and Imamura T: Coordinate regulation of cell growth and differentiation by TGF-beta superfamily and Runx proteins. Oncogene 23: 4232-4237, 2004.

4. Stifani S and Ma Q: 'Runxs and regulations' of sensory and motor neuron subtype differentiation: Implications for hematopoietic development. Blood Cells Mol Dis 43: 20-26, 2009.

5. Chuang LS and Ito Y: RUNX3 is multifunctional in carcinogenesis of multiple solid tumors. Oncogene 29: 2605-2615, 2010.

6. Lee SH, Kim J, Kim WH and Lee YM: Hypoxic silencing of tumor suppressor RUNX3 by histone modification in gastric cancer cells. Oncogene 28: 184-194, 2009.
7. Patan S: Vasculogenesis and angiogenesis. Cancer Treat Res 117: 3-32, 2004.

8. Urbich $\mathrm{C}$ and Dimmeler S: Endothelial progenitor cells: Characterization and role in vascular biology. Circ Res 95: 343-353, 2004.

9. Asahara T and Kawamoto A: Endothelial progenitor cells for postnatal vasculogenesis. Am J Physiol Cell Physiol 287: C572-C579, 2004.

10. Moschetta M, Mishima Y, Sahin I, Manier S, Glavey S, Vacca A, Roccaro AM and Ghobrial IM: Role of endothelial progenitor cells in cancer progression. Biochim Biophys Acta 1846: 26-39, 2014.

11. Nolan DJ, Ciarrocchi A, Mellick AS, Jaggi JS, Bambino K, Gupta S, Heikamp E, McDevitt MR, Scheinberg DA, Benezra R, et al: Bone marrow-derived endothelial progenitor cells are a major determinant of nascent tumor neovascularization. Genes Dev 21: 1546-1558, 2007.

12. Obi S, Yamamoto K, Shimizu N, Kumagaya S, Masumura T, Sokabe T, Asahara T and Ando J: Fluid shear stress induces arterial differentiation of endothelial progenitor cells. J Appl Physiol (1985) 106: 203-211, 2009.

13. Masuda H, Alev C, Akimaru H, Ito R, Shizuno T, Kobori M, Horii M, Ishihara T, Isobe K, Isozaki M, et al: Methodological development of a clonogenic assay to determine endothelial progenitor cell potential. Circ Res 109: 20-37, 2011.

14. Kwon SM, Lee YK, Yokoyama A, Jung SY, Masuda H, Kawamoto A, Lee YM and Asahara T: Differential activity of bone marrow hematopoietic stem cell subpopulations for EPC development and ischemic neovascularization. J Mol Cell Cardiol 51: 308-317, 2011

15. Hur J, Yang HM, Yoon CH, Lee CS, Park KW, Kim JH, Kim TY, Kim JY, Kang HJ, Chae IH, et al: Identification of a novel role of T cells in postnatal vasculogenesis: Characterization of endothelial progenitor cell colonies. Circulation 116: 1671-1682, 2007.

16. Kalka C, Masuda H, Takahashi T, Kalka-Moll WM, Silver M, Kearney M, Li T, Isner JM and Asahara T: Transplantation of ex vivo expanded endothelial progenitor cells for therapeutic neovascularization. Proc Natl Acad Sci USA 97: 3422-3427, 2000.

17. Schwarz TM, Leicht SF, Radic T, Rodriguez-Arabaolaza I, Hermann PC, Berger F, Saif J, Böcker W, Ellwart JW, Aicher A, et al: Vascular incorporation of endothelial colony-forming cells is essential for functional recovery of murine ischemic tissue following cell therapy. Arterioscler Thromb Vasc Biol 32: e13-e21, 2012.

18. Lee SH, Lee JH,Han YS, Ryu JM, Yoon YM and Han HJ: Hypoxia accelerates vascular repair of endothelial colony-forming cells on ischemic injury via STAT3-BCL3 axis. Stem Cell Res Ther 6: 139, 2015.

19. Moccia F, Zuccolo E, Poletto V, Cinelli M, Bonetti E, Guerra G and Rosti V: Endothelial progenitor cells support tumour growth and metastatisation: Implications for the resistance to anti-angiogenic therapy. Tumour Biol 36: 6603-6614, 2015.

20. Lee SH, Bae SC, Kim KW and Lee YM: RUNX3 inhibits hypoxia-inducible factor- $1 \alpha$ protein stability by interacting with prolyl hydroxylases in gastric cancer cells. Oncogene 33: 1458-1467, 2014.

21. Choi JH, Nguyen MP, Lee D, Oh GT and Lee YM: Hypoxia-induced endothelial progenitor cell function is blunted in angiotensinogen knockout mice. Mol Cells 37: 487-496, 2014.

22. Benito J, Zeng Z, Konopleva M and Wilson WR: Targeting hypoxia in the leukemia microenvironment. Int J Hematol Oncol 2: 279-288, 2013

23. Gaidzik VI, Teleanu V, Papaemmanuil E, Weber D, Paschka P, Hahn J, Wallrabenstein T, Kolbinger B, Köhne CH, Horst HA, et al: RUNX1 mutations in acute myeloid leukemia are associated with distinct clinico-pathologic and genetic features. Leukemia 30: 2160-2168, 2016.

24. Li QL, Ito K, Sakakura C, Fukamachi H, Inoue K, Chi XZ, Lee KY, Nomura S, Lee CW, Han SB, et al: Causal relationship between the loss of RUNX3 expression and gastric cancer. Cell 109: 113-124, 2002.

25. Kwon SM, Eguchi M, Wada M, Iwami Y, Hozumi K, Iwaguro H, Masuda H, Kawamoto A and Asahara T: Specific Jagged-1 signal from bone marrow microenvironment is required for endothelial progenitor cell development for neovascularization. Circulation 118: 157-165, 2008.

26. Tanaka R, Wada M, Kwon SM, Masuda H, Carr J, Ito R, Miyasaka M, Warren SM, Asahara T and Tepper OM: The effects of flap ischemia on normal and diabetic progenitor cell function. Plast Reconstr Surg 121: 1929-1942, 2008. 
27. Choi JH, Nguyen MP, Jung SY, Kwon SM, Jee JG, Bae JS, Lee S, Lee MY and Lee YM: Inhibitory effect of glyceollins on vasculogenesis through suppression of endothelial progenitor cell function. Mol Nutr Food Res 57: 1762-1771, 2013.

28. Nguyen MP, Lee D, Lee SH, Lee HE, Lee HY and Lee YM: Deguelin inhibits vasculogenic function of endothelial progenitor cells in tumor progression and metastasis via suppression of focal adhesion. Oncotarget 6: 16588-16600, 2015.

29. Biscetti F, Straface G, Arena V, Stigliano E, Pecorini G, Rizzo P, De Angelis G, Iuliano L, Ghirlanda G and Flex A: Pioglitazone enhances collateral blood flow in ischemic hindlimb of diabetic mice through an Akt-dependent VEGF-mediated mechanism, regardless of PPARgamma stimulation. Cardiovasc Diabetol 8: 49, 2009.

30. Yamaguchi J, Kusano KF, Masuo O, Kawamoto A, Silver M, Murasawa S, Bosch-Marce M, Masuda H, Losordo DW, Isner JM, et al: Stromal cell-derived factor-1 effects on ex vivo expanded endothelial progenitor cell recruitment for ischemic neovascularization. Circulation 107: 1322-1328, 2003.

31. Kucia M, Jankowski K, Reca R, Wysoczynski M, Bandura L, Allendorf DJ, Zhang J, Ratajczak J and Ratajczak MZ: CXCR4-SDF-1 signalling, locomotion, chemotaxis and adhesion. J Mol Histol 35: 233-245, 2004.

32. Okabe S, Fukuda S, Kim YJ, Niki M, Pelus LM, Ohyashiki K, Pandolfi PP and Broxmeyer HE: Stromal cell-derived factor-1alpha/CXCL12-induced chemotaxis of T cells involves activation of the RasGAP-associated docking protein p62Dok-1. Blood 105: 474-480, 2005.

33. Matsumoto $\mathrm{T}$ and Claesson-Welsh L: VEGF receptor signal transduction. Sci STKE 2001: re21, 2001

34. Zheng H, Fu G, Dai T and Huang H: Migration of endothelial progenitor cells mediated by stromal cell-derived factor-1alpha/CXCR4 via PI3K/Akt/eNOS signal transduction pathway. J Cardiovasc Pharmacol 50: 274-280, 2007.

35. Llevadot $\mathrm{J}$ and Asahara T: Effects of statins on angiogenesis and vasculogenesis. Rev Esp Cardiol 55: 838-844, 2002.

36. Ramakrishnan S, Anand V and Roy S: Vascular endothelial growth factor signaling in hypoxia and inflammation. J Neuroimmune Pharmacol 9: 142-160, 2014.

37. Wu Y, Jin M, Xu H, Shimin Z, He S, Wang L and Zhang Y: Clinicopathologic significance of HIF-1 $\alpha$, CXCR4, and VEGF expression in colon cancer. Clin Dev Immunol 2010: 537531, 2010.

38. Asahara T, Murohara T, Sullivan A, Silver M, van der Zee R, Li T, Witzenbichler B, Schatteman G and Isner JM: Isolation of putative progenitor endothelial cells for angiogenesis. Science 275: 964-967, 1997.

39. Iwami Y, Masuda H and Asahara T: Endothelial progenitor cells: Past, state of the art, and future. J Cell Mol Med 8: 488-497, 2004

40. Asahara T, Kawamoto A and Masuda H: Concise review: Circulating endothelial progenitor cells for vascular medicine. Stem Cells 29: 1650-1655, 2011.

41. Peng Z, Wei D, Wang L, Tang H, Zhang J, Le X, Jia Z, Li Q and Xie K: RUNX3 inhibits the expression of vascular endothelial growth factor and reduces the angiogenesis, growth, and metastasis of human gastric cancer. Clin Cancer Res 12: 6386-6394, 2006

42. Takakura N, Watanabe T, Suenobu S, Yamada Y, Noda T, Ito Y, Satake M and Suda T: A role for hematopoietic stem cells in promoting angiogenesis. Cell 102: 199-209, 2000.
43. Ter Elst A, Ma B, Scherpen FJ, de Jonge HJ, Douwes J, Wierenga AT, Schuringa JJ, Kamps WA and de Bont ES: Repression of vascular endothelial growth factor expression by the runt-related transcription factor 1 in acute myeloid leukemia. Cancer Res 71: 2761-2771, 2011.

44. Kalev-Zylinska ML, Horsfield JA, Flores MV, Postlethwait JH, Vitas MR, Baas AM, Crosier PS and Crosier KE: Runx1 is required for zebrafish blood and vessel development and expression of a human RUNX1-CBF2T1 transgene advances a model for studies of leukemogenesis. Development 129: 2015-2030, 2002.

45. Spender LC, Whiteman HJ, Karstegl CE and Farrell PJ: Transcriptional cross-regulation of RUNX1 by RUNX3 in human B cells. Oncogene 24: 1873-1881, 2005.

46. Medina RJ, O'Neill CL, Sweeney M, Guduric-Fuchs J, Gardiner TA, Simpson DA and Stitt AW: Molecular analysis of endothelial progenitor cell (EPC) subtypes reveals two distinct cell populations with different identities. BMC Med Genomics 3: $18,2010$.

47. Fainaru O, Shseyov D, Hantisteanu S and Groner Y: Accelerated chemokine receptor 7-mediated dendritic cell migration in Runx3 knockout mice and the spontaneous development of asthma-like disease. Proc Natl Acad Sci USA 102: 10598-10603, 2005.

48. Ehlers M, Laule-Kilian K, Petter M, Aldrian CJ, Grueter B, Würch A, Yoshida N, Watanabe T, Satake M and Steimle V: Morpholino antisense oligonucleotide-mediated gene knockdown during thymocyte development reveals role for Runx 3 transcription factor in CD4 silencing during development of CD4-/CD8+ thymocytes. J Immunol 171: 3594-3604, 2003.

49. Taniuchi I, Osato M, Egawa T, Sunshine MJ, Bae SC, Komori T, Ito Y and Littman DR: Differential requirements for Runx proteins in CD4 repression and epigenetic silencing during T lymphocyte development. Cell 111: 621-633, 2002.

50. Le XF, Groner Y, Kornblau SM, Gu Y, Hittelman WN, Levanon D, Mehta K, Arlinghaus RB and Chang KS: Regulation of AML2/CBFA3 in hematopoietic cells through the retinoic acid receptor alpha-dependent signaling pathway. J Biol Chem 274: 21651-21658, 1999.

51. Gomes I, Sharma TT, Edassery S, Fulton N, Mar BG and Westbrook CA: Novel transcription factors in human CD34 antigen-positive hematopoietic cells. Blood 100: 107-119, 2002.

52. Leone AM, Valgimigli M, Giannico MB, Zaccone V, Perfetti M, D'Amario D, Rebuzzi AG and Crea F: From bone marrow to the arterial wall: The ongoing tale of endothelial progenitor cells. Eur Heart J 30: 890-899, 2009.

53. Asahara T, Takahashi T, Masuda H, Kalka C, Chen D, Iwaguro H, Inai Y, Silver M and Isner JM: VEGF contributes to postnatal neovascularization by mobilizing bone marrow-derived endothelial progenitor cells. EMBO J 18: 3964-3972, 1999.

54. Carmeliet P, Dor Y, Herbert JM, Fukumura D, Brusselmans K, Dewerchin M, Neeman M, Bono F, Abramovitch R, Maxwell P, et al: Role of HIF-1alpha in hypoxia-mediated apoptosis, cell proliferation and tumour angiogenesis. Nature 394: 485-490, 1998. 